\title{
Physicochemical Evaluation of Biofield Treated Peptone and Malmgren Modified Terrestrial Orchid Medium
}

\author{
Mahendra Kumar Trivedi ${ }^{1}$, Alice Branton ${ }^{1}$, Dahryn Trivedi ${ }^{1}$, Gopal Nayak ${ }^{1}$, \\ Rakesh Kumar Mishra ${ }^{2}$, Snehasis Jana ${ }^{2, *}$ \\ ${ }^{1}$ Trivedi Global Inc., Henderson, USA \\ ${ }^{2}$ Trivedi Science Research Laboratory Pvt. Ltd., Bhopal, Madhya Pradesh, India
}

\section{Email address:}

publication@trivedisrl.com (S. Jana)

\section{To cite this article:}

Mahendra Kumar Trivedi, Alice Branton, Dahryn Trivedi, Gopal Nayak, Rakesh Kumar Mishra, Snehasis Jana. Physicochemical Evaluation of Biofield Treated Peptone and Malmgren Modified Terrestrial Orchid Medium. American Journal of Bioscience and Bioengineering. Vol. 3, No. 6, 2015, pp. 169-177. doi: 10.11648/j.bio.20150306.15

\begin{abstract}
Peptone and Malmgren modified terrestrial orchid (MMTO) has been used as a growth medium for tissue culture applications. This research study was conducted to explore the influence of Mr. Trivedi's biofield energy treatment on physicochemical properties of peptone and MMTO. The study was performed in two groups i.e. control and treated. The control group was kept aside as untreated, and the treated group was received the biofield energy treatment. The control and treated samples were further subjected to characterization by X-ray diffraction (XRD), differential scanning calorimetry (DSC), thermogravimetric analysis (TGA), Fourier transform infrared (FT-IR) spectroscopy, particle size analyzer and surface area analyzer. The XRD analysis revealed the amorphous nature of the control and treated peptone samples. The DSC analysis showed an increase in thermal denaturation temperature of the treated peptone $\left(196.22^{\circ} \mathrm{C}\right)$ as compared to the control sample $\left(141.20^{\circ} \mathrm{C}\right)$. Additionally, the exothermic peak of treated sample $\left(280^{\circ} \mathrm{C}\right)$ was increased as compared to the control $\left(270^{\circ} \mathrm{C}\right)$. The DSC of control and treated MMTO showed the absence of the melting temperature in their respective DSC thermograms. The TGA analysis of the treated peptone showed an increase in onset of thermal degradation $\left(172^{\circ} \mathrm{C}\right)$ with respect to the control $\left(170^{\circ} \mathrm{C}\right)$. Nevertheless, the TGA thermogram of the treated MMTO $\left(293.96^{\circ} \mathrm{C}\right)$ showed an increase in maximum thermal degradation temperature $\left(\mathrm{T}_{\max }\right)$ as compared with the control $\left(281.41^{\circ} \mathrm{C}\right)$. It indicated the good thermal stability of the treated peptone and MMTO samples. The FT-IR result of the treated peptone showed an upward shift in C-H $\left(2817 \rightarrow 2833 \mathrm{~cm}^{-1}\right)$, and amide I $\left(1635 \rightarrow 1641 \mathrm{~cm}^{-1}\right)$, stretching in the treated sample with respect to the control sample. Whereas, the FT-IR spectrum of the treated MMTO showed an increase in the frequency of the C-H $\left(2817 \rightarrow 2833 \mathrm{~cm}^{-1}\right)$ and amide I $\left(1596 \rightarrow 1606 \mathrm{~cm}^{-1}\right)$ bands as compared to the control. Particle size analysis of the treated peptone showed an increase in $\mathrm{d}_{50}$ (average particle size) and $\mathrm{d}_{99}$ (size exhibited by $99 \%$ of particles) by 9.3 and $41.4 \%$, respectively with respect to the control. Surface area analysis showed increase in surface area by $4.3 \%$ in the treated peptone. Altogether, the results corroborated that the biofield energy treatment had altered the physical, thermal and spectral properties of peptone and MMTO. It is assumed that biofield treated peptone and MMTO could be utilized as potential candidates for cell culture applications.
\end{abstract}

Keywords: Biofield Energy Treatment, Peptone, Malmgren Modified Terrestrial Orchid, Thermal Analysis

\section{Introduction}

Tissue culture is a generally used term for the removal of cells, tissues, or organs from an animal and their placement into an artificial environment conductive to growth. It is well known as the techniques of keeping tissues alive and growing in an appropriate culture medium. It was reported that growing tissues of living organism outside the body are made possible in an appropriate culture medium, containing a mixture of nutrient either in solid or liquid form. At present significant progress has been made in the field of animal cell culture $[1,2]$. Generally a growth medium or cell culture medium is developed to assist the growth of microorganisms or cells [3]. There are different type of medium have been used to grow many kinds of cells. There are two types of growth media, which commonly used for supporting the growth of microorganisms such as yeast and bacteria. It was reported that few organisms such as fastidious require 
specialized environment due to complex nutritional requirements. Additionally, viruses that are known as obligate intracellular parasites require tissue culture medium consisting of living cells [4]. Peptone (bacteriological) is obtained through enzymatic digestion of selected fresh meat. Due to its high nutrition value it assists the growth of the various microorganisms and used for the identification of the bacteria by performing various biochemical tests. Additionally, due to its nutritious nature, mainly at lower dilutions, for the recombinant cell lines it has been used as an additive medium for the production of recombinant therapeutic protein in high-density perfusion culture of mammalian cells [5]. The stability of proteins at higher temperature is a major issue that hampers its applications in many targeted areas [6, 7]. Bischof et al. reported that it is imperative to understand that how protein loses stability and to what extent one can control this through the thermal environment as well as through chemical and mechanical modification of the protein structure [8].

On the other hand, Malmgren modified terrestrial orchid (MMTO) has been used as tissue culture medium for in vitro culture of orchids. It is mainly composed of glycine, casein hydrolysate, and agar as nutrients to support the culture growth. However, it is known to be hygroscopic in nature that might affect its end uses as plant tissue culture growth medium [9]. Therefore, some alternative strategies should be considered to alleviate the thermal stability of peptone and hygroscopic nature of MMTO. Recently, biofield energy treatment was used to modify the physicochemical properties of various materials.

Biofield energy treatments are comprised of practices based on subtle energy field and generally it reflects the concept that human beings are infused with this form of energy [10]. It was shown that a unique bioenergetic field surrounds and permeates the human body [11]. This bioenergetic field controls the human wellbeing and during disease condition this unique field is depleted [12]. Recently some medical technologies were deployed to measure this human biofield [13]. Moreover, biofield energy therapies are categorized under complementary and alternative medicine (CAM). CAM is approved by National Centre for Complementary and Alternative Medicine (NCCAM)/ National Institute of Health (NIH) as an alternative treatment in health care sector [14]. Therefore, it is envisaged that human beings have the ability to harness the energy from the environment/Universe and it can transmit into any object (living or non-living) around the Globe. The object(s) are always received the energy and responding in a useful manner that is called biofield energy.

Mr. Mahendra Kumar Trivedi is known to transform the characteristics of various living and non-living things using his unique biofield energy. This biofield energy treatment is also known as The Trivedi Effect ${ }^{\circledR}$. This unique biofield treatment has altered the characteristics of pathogenic microbes [15] and improved the production in agriculture [16]. Moreover, biofield energy has modified the physicochemical properties of metal [17], drugs [18] and organic products [19].

After conceiving above-mentioned excellent outcome from biofield energy treatment and properties of peptone and MMTO, this work was planned to investigate the impact of this treatment on its physicochemical properties.

\section{Materials and Methods}

Peptone and Malmgren modified terrestrial orchid (MMTO) medium were procured from Himedia Laboratories, India, and the samples were separated into two parts. The one part was kept aside as a control sample, while the other part was subjected to Mr. Trivedi's unique biofield energy treatment and coded as the treated sample. Both the groups were in sealed pack, while the treated group was handed over to Mr. Trivedi for biofield energy treatment under standard laboratory conditions. Mr. Trivedi gave the energy treatment through his energy transmission process to the treated samples without touching the samples. The control and treated samples were characterized by different analytical techniques such as X-ray diffraction, differential scanning calorimetry, thermogravimetric analysis, Fourier transform infrared spectroscopy, particle size analyzer, and surface area analyzer. All the experimental techniques were not assessed by quantitative analysis with this analytical data, does not require replication of points or statistical analysis.

\subsection{X-ray Diffraction (XRD)}

XRD analysis of control and treated peptone was evaluated using X-ray diffractometer system, Phillips, Holland PW 1710 which consist of a copper anode with nickel filter. XRD system had a radiation of wavelength $1.54056 \AA$.

\subsection{Differential Scanning Calorimetry (DSC)}

The control and treated samples (peptone and MMTO) were analyzed using Pyris-6 Perkin Elmer DSC at a $10^{\circ} \mathrm{C}$ $/ \mathrm{min}$ heating rate and the air was purged at a flow rate of 5 $\mathrm{mL} / \mathrm{min}$. The predetermined amount of sample was kept in an aluminum pan and closed with a lid. A reference sample was prepared using a blank aluminum pan. The percentage change in latent heat of fusion was calculated using following equations:

$$
\begin{gathered}
\% \text { Change in latent heat of fusion } \\
=\frac{[\Delta \mathrm{H} \text { Treated }-\Delta \mathrm{H} \text { Control }]}{\Delta \mathrm{H} \text { Control } \times 100}
\end{gathered}
$$

Where, $\Delta \mathrm{H}_{\text {Control }}$ and $\Delta \mathrm{H}_{\text {Treated }}$ are the latent heat of fusion of control and treated samples, respectively.

\subsection{Thermogravimetric Analysis-Differential Thermal Analysis (TGA-DTA)}

A Mettler Toledo simultaneous TGA and differential thermal analyzer (DTA) was used to investigate the thermal stability of control and treated samples (peptone and MMTO). The rate of heating was $5^{\circ} \mathrm{C} / \mathrm{min}$ and samples were heated in the range of room temperature to $400^{\circ} \mathrm{C}$ under air atmosphere. 


\subsection{FT-IR Spectroscopy}

The FT-IR spectra were recorded on Shimadzu's Fourier transform infrared spectrometer (Japan) with the frequency range of $4000-500 \mathrm{~cm}^{-1}$.

\subsection{Particle Size Analysis}

A Sympetac Helos-BF Laser Particle Size Analyzer with a detection range of $0.1 \mu \mathrm{m}$ to $875 \mu \mathrm{m}$ was used to analyze the particle size distribution. Average particle size $\mathrm{d}_{50}$ and $\mathrm{d}_{99}$, size exhibited by $99 \%$ of powder particles were computed from laser diffraction data. The $\mathrm{d}_{50}$ and $\mathrm{d}_{99}$ were calculated by the following formula:

Percentage change in $d_{50}$ size $=100 \times\left(d_{50}\right.$ treated- $d_{50}$ control)/ $\mathrm{d}_{50}$ control.

Percentage Change in $\mathrm{d}_{99}$ size $=100 \times\left(\mathrm{d}_{99}\right.$ treated- $\mathrm{d}_{99}$ control)/ $\mathrm{d}_{99}$ control.

\subsection{Surface Area Analysis}

A surface area analyzer, SMART SORB 90 BET, which had a detection range of $0.1-100 \mathrm{~m}^{2} / \mathrm{g}$ was used to evaluate the surface area of the control and treated peptone samples.

\section{Results and Discussion}

\subsection{X-ray Diffraction Pattern}
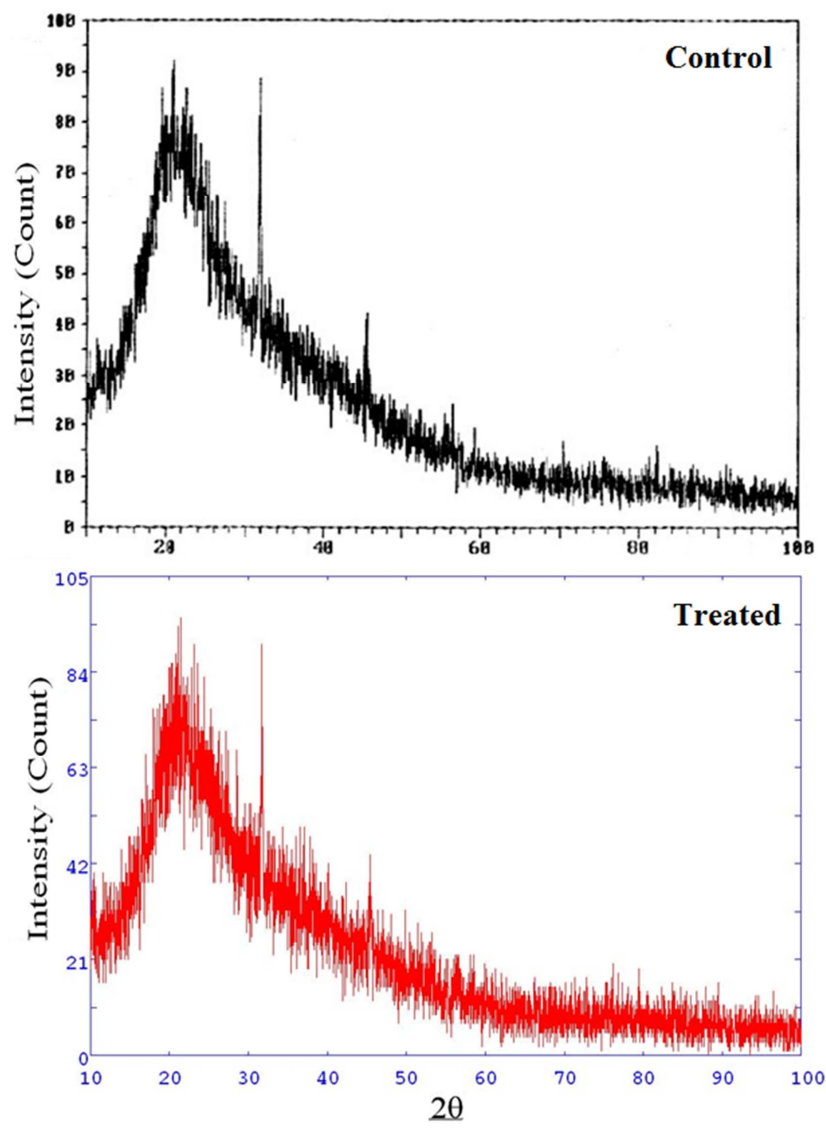

Figure 1. XRD diffractogram of the control and treated peptone.

XRD diffractogram of the control and treated peptone are presented in Fig. 1. XRD diffractogram of the control peptone showed a broad peak at Braggs angle $22^{\circ}$. This peak was mainly due to amorphous regions present in the sample. The diffractogram showed few intense XRD peaks at $31.69^{\circ}$ and $45.41^{\circ}$ that might be associated with semicrystalline regions present in the peptone. Likewise, the XRD diffractogram of the treated peptone showed XRD peaks at Bragg's angle $23^{\circ}, 31.76^{\circ}$, and $45.44^{\circ}$. All these peaks exhibited both amorphous non-regular pattern and semicrystalline regions present in the treated sample. Additionally, the result indicated an increase in the Braggs angle of the XRD peaks $31.69^{\circ} \rightarrow 31.76^{\circ}$ and $45.41^{\circ} \rightarrow 45.44^{\circ}$ in the treated sample as compared to the control sample. It was reported that presence of tensile stress in molecules might cause increase in Bragg's angle of the samples [20]. Thus, it is assumed that biofield energy treatment might cause the emergence of tensile stress in the treated peptone molecules that led to increase in Bragg's angle of the sample as compared to the control.

\subsection{Differential Scanning Calorimetry}

DSC is a well-known technique to evaluate the thermal properties such as glass transition, melting temperature, crystallization temperature and latent heat of vaporization in the samples. The DSC thermograms of control and treated peptone are presented in Fig. 2. The DSC thermogram of the control peptone showed an endothermic transition at $141.20^{\circ} \mathrm{C}$. It was reported that major endothermic peak observed (from 0 to $180^{\circ} \mathrm{C}$ ) in different proteins such as gelatin, soy protein, sodium casein and corn gluten have been attributed to the loss of residual water or hydrogen bond disruption between the molecules [21-23]. This endothermic peak can also be attributed to thermal denaturation of the control sample. However, in the DSC thermogram of treated peptone the endothermic peak appeared was broad in nature and the peak was centered at $196.22^{\circ} \mathrm{C}$. This indicated the substantial increase in the thermal denaturation temperature of the treated protein (peptone) sample as compared to the control. Tang et al. observed a similar increase in thermal denaturation temperature during their studies on transglutaminase treated soy protein isolates. They proposed that formation of covalent crosslinks along with subsequent hydrophobic interaction between protein and microbial transglutaminase might increase the thermal stability of the sample [24]. Hence, it is hypothesized that biofield energy treatment perhaps induced covalent crosslinking and hydrophobic protein interactions that led to increase the thermal denaturation temperature of the treated peptone as compared to the control. Additionally, the DSC thermograms of the control and treated peptone showed the presence of exothermic peaks at around $270^{\circ} \mathrm{C}$ and $280^{\circ} \mathrm{C}$, respectively. This indicated an increase in the exothermic peak of the treated peptone as compared to the control. The protein architecture is maintained by inherent hydrogen bonding and electrostatic interactions, whereas the thermal stability is governed by hydrophobic interactions. Researchers have elaborated that if the hydrophilic interactions retaining the 
tertiary protein structure are broken by heating, the hydrophobic regions hidden inside the protein structure will be exposed towards the surface and merge with other hydrophobic proteins to form aggregates. Therefore, it was shown that exothermic peaks in proteins arise due to the protein aggregation $[25,26]$. Similarly, it is assumed that biofield energy treatment might cause more protein aggregation in peptone that lead to increase in exothermic peak as compared to the control.

The latent heat of fusion of the control and treated samples are recorded from the DSC thermograms. The latent heat of fusion of the control peptone was $167.61 \mathrm{~J} / \mathrm{g}$, and it was increased to $179.61 \mathrm{~J} / \mathrm{g}$ in the treated peptone. The result indicated $7.16 \%$ increase in latent heat of fusion of the treated peptone as compared to the control sample. It is assumed that biofield energy treatment might alter the internal energy of the treated peptone that lead to increase in latent heat of fusion as compared to the control.

The DSC thermogram of the control and treated MMTO are presented in Fig. 3. The DSC thermogram of the control sample showed a broad endothermic peak at $85.31^{\circ} \mathrm{C}$ that may be attributed to the associated water in the control sample. However, DSC thermograms of both control and treated MMTO showed absence of the melting endothermic peaks. This might be due to robust crystalline nature of the control and treated samples that led to disappearance of the melting peaks.

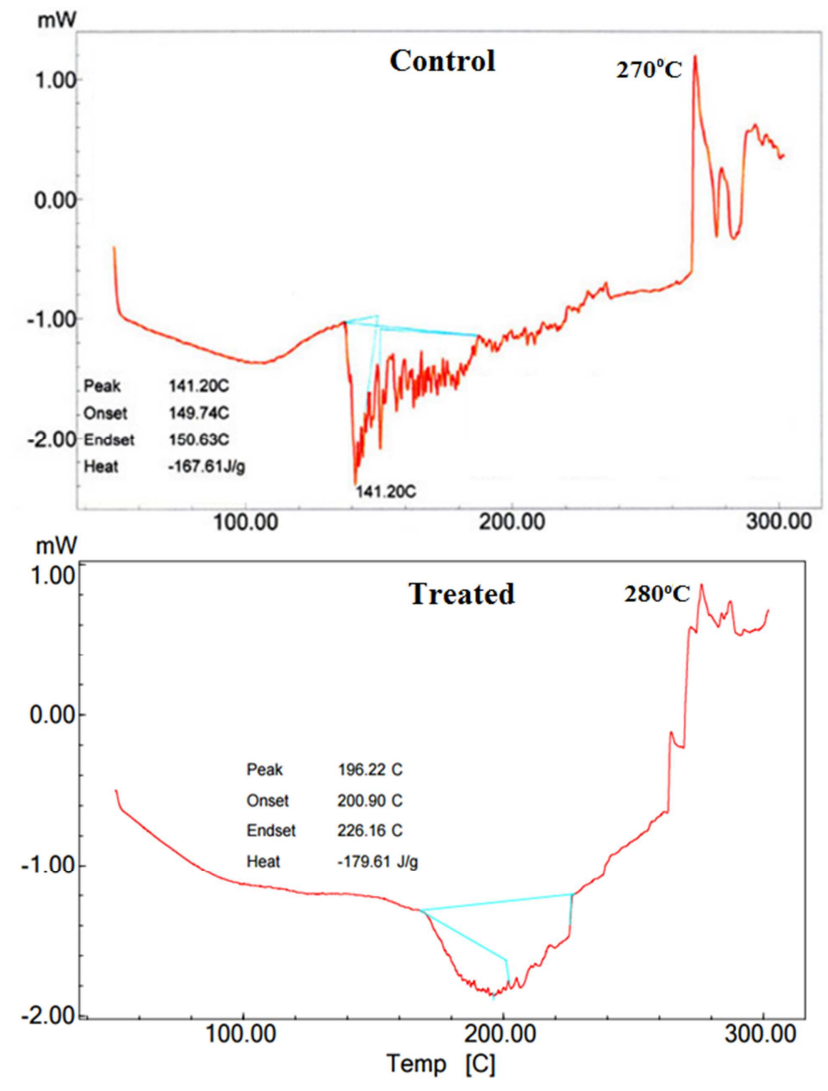

Figure 2. DSC thermogram of the control and treated peptone.
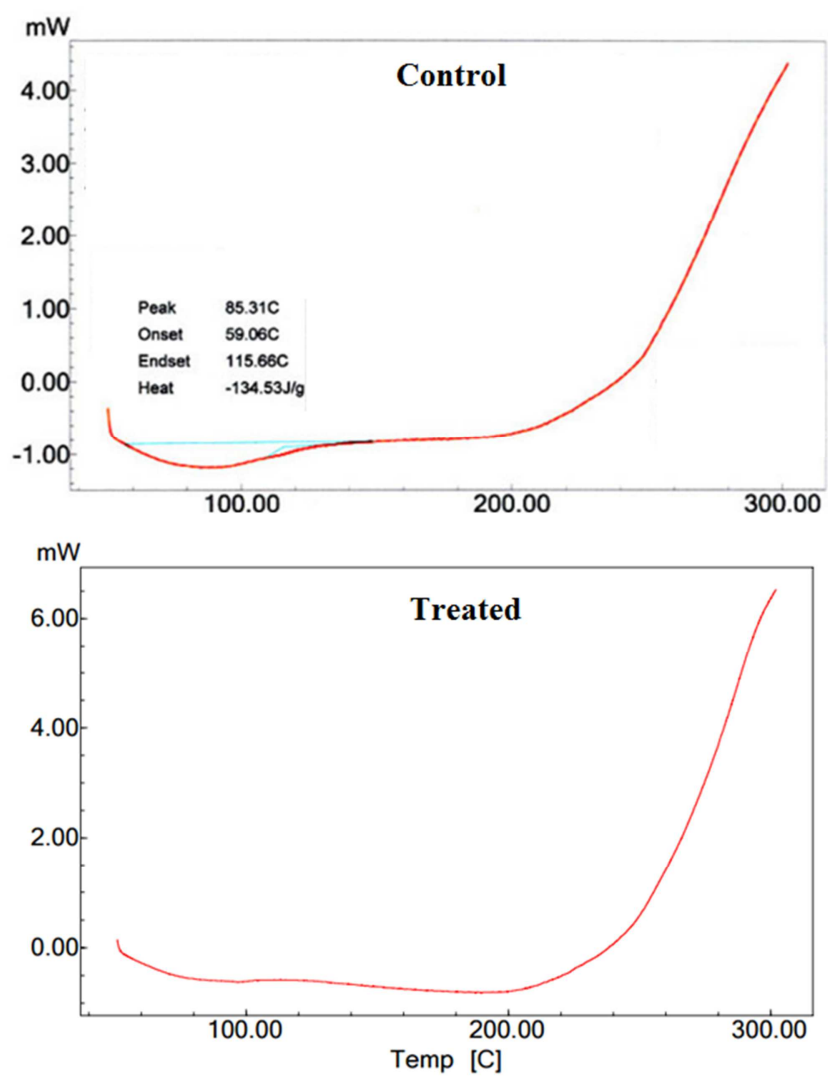

Figure 3. DSC thermogram of the control and treated MMTO.

\subsection{TGA Analysis}

TGA analysis is mainly used to know the thermal properties such as thermal stability, thermal decomposition, and oxidation of the materials. The TGA thermograms of the control and treated peptone are presented in Fig. 4. The TGA thermogram of the control peptone showed two-step thermal degradation pattern. The first thermal degradation process started at around $170^{\circ} \mathrm{C}$ and terminated at $280^{\circ} \mathrm{C}$. The second thermal degradation event started at around $292^{\circ} \mathrm{C}$ and terminated at $375^{\circ} \mathrm{C}$. During both the thermal events the control samples lost $24.77 \%$ and $21.39 \%$ from the initial sample weight. The TGA thermogram of the treated peptone also exhibited two-step thermal degradation pattern. The thermal degradation started at around $172^{\circ} \mathrm{C}$, and it stopped at $250^{\circ} \mathrm{C}$. Subsequently, the second thermal degradation process began at around $255^{\circ} \mathrm{C}$ and ended at $385^{\circ} \mathrm{C}$. The treated peptone lost $17.38 \%$ and $27.60 \%$ weight from its initial sample weight. The result suggested that onset of thermal degradation was increased slightly in treated peptone $\left(172^{\circ} \mathrm{C}\right)$ as compared to the control $\left(170^{\circ} \mathrm{C}\right)$. The weight loss of the treated peptone sample was less $(17.38 \%)$ as compared to the control sample $(24.77 \%)$ that may be inferred as an increase in thermal stability of the treated peptone with respect to the control. The maximum thermal degradation temperature $\left(\mathrm{T}_{\max }\right)$ was recorded from the Derivative thermogravimetry (DTG) thermogram of the samples. The $\mathrm{T}_{\max }$ of the control and treated peptone were $228.32^{\circ} \mathrm{C}$ and $216.98^{\circ} \mathrm{C}$, respectively. 
TGA thermograms of the control and treated MMTO are depicted in Fig. 5. The TGA thermogram of the control sample showed two-step thermal degradation pattern. The thermal degradation started at around $189^{\circ} \mathrm{C}$ and terminated at $220^{\circ} \mathrm{C}$. The second thermal degradation commenced at around $250^{\circ} \mathrm{C}$ and stopped at $333^{\circ} \mathrm{C}$. During this process, the control sample lost $6.68 \%$ and $43.72 \%$ of its initial weight. Nevertheless, the treated MMTO sample started to degrade thermally at around $241{ }^{\circ} \mathrm{C}$ and stopped at $390^{\circ} \mathrm{C}$. The treated sample showed major weight loss by $60.88 \%$ during this process. The DTG thermogram of the control sample showed $\mathrm{T}_{\max }$ at $281.41^{\circ} \mathrm{C}$, and it was increased up to $293.96^{\circ} \mathrm{C}$ in the treated sample. This may be inferred as the higher thermal stability of the treated MMTO as compared to the control sample. In recent literature, it was reported that crosslinking and conformational changes might increase the thermal stability of a compound [27]. Thus, it is assumed that biofield treatment may act as a crosslinker and induced conformational changes that lead to increase the thermal stability of the treated sample.
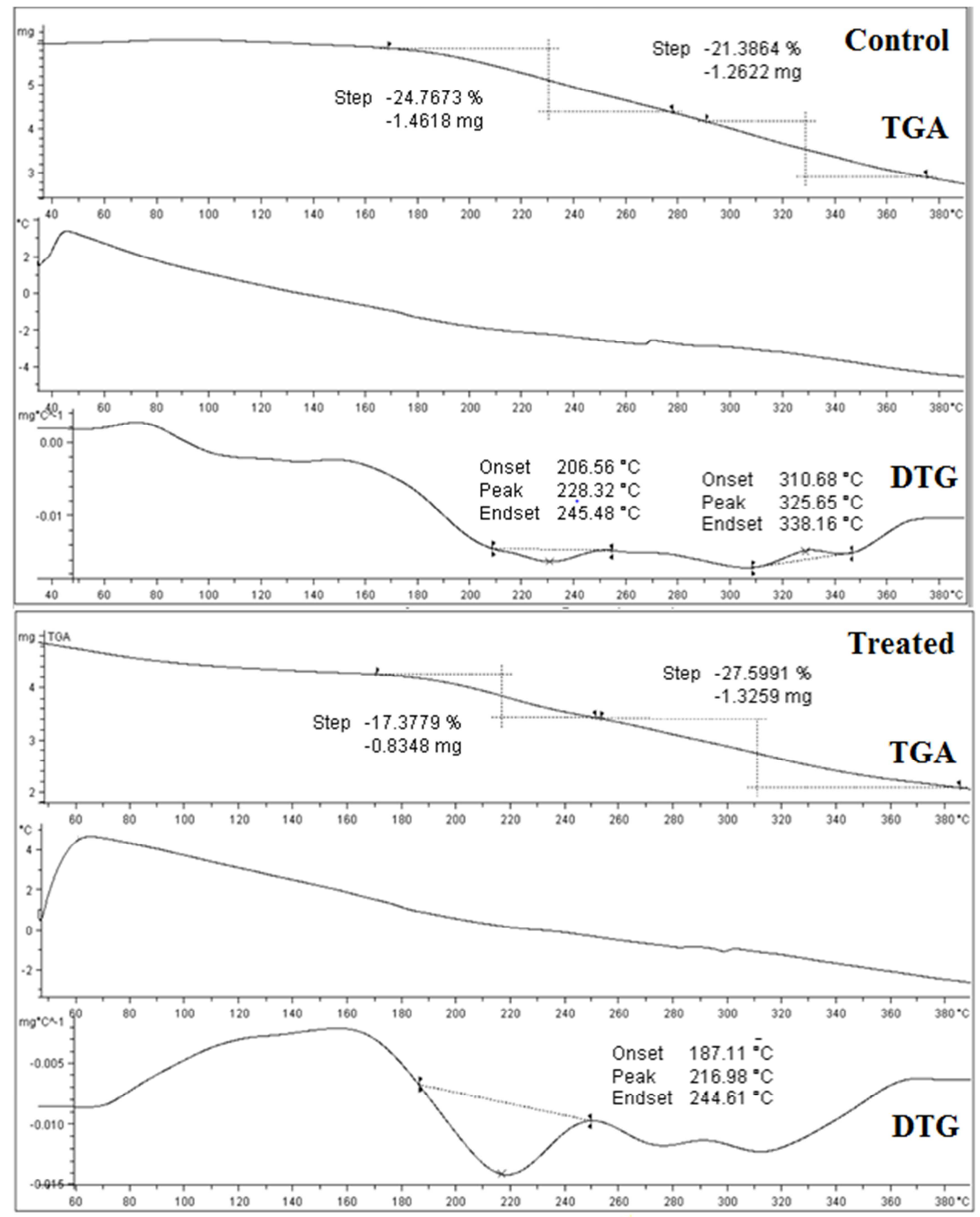

Temperature $\left({ }^{\circ} \mathrm{C}\right)$

Figure 4. TGA thermograms of the control and treated peptone. 

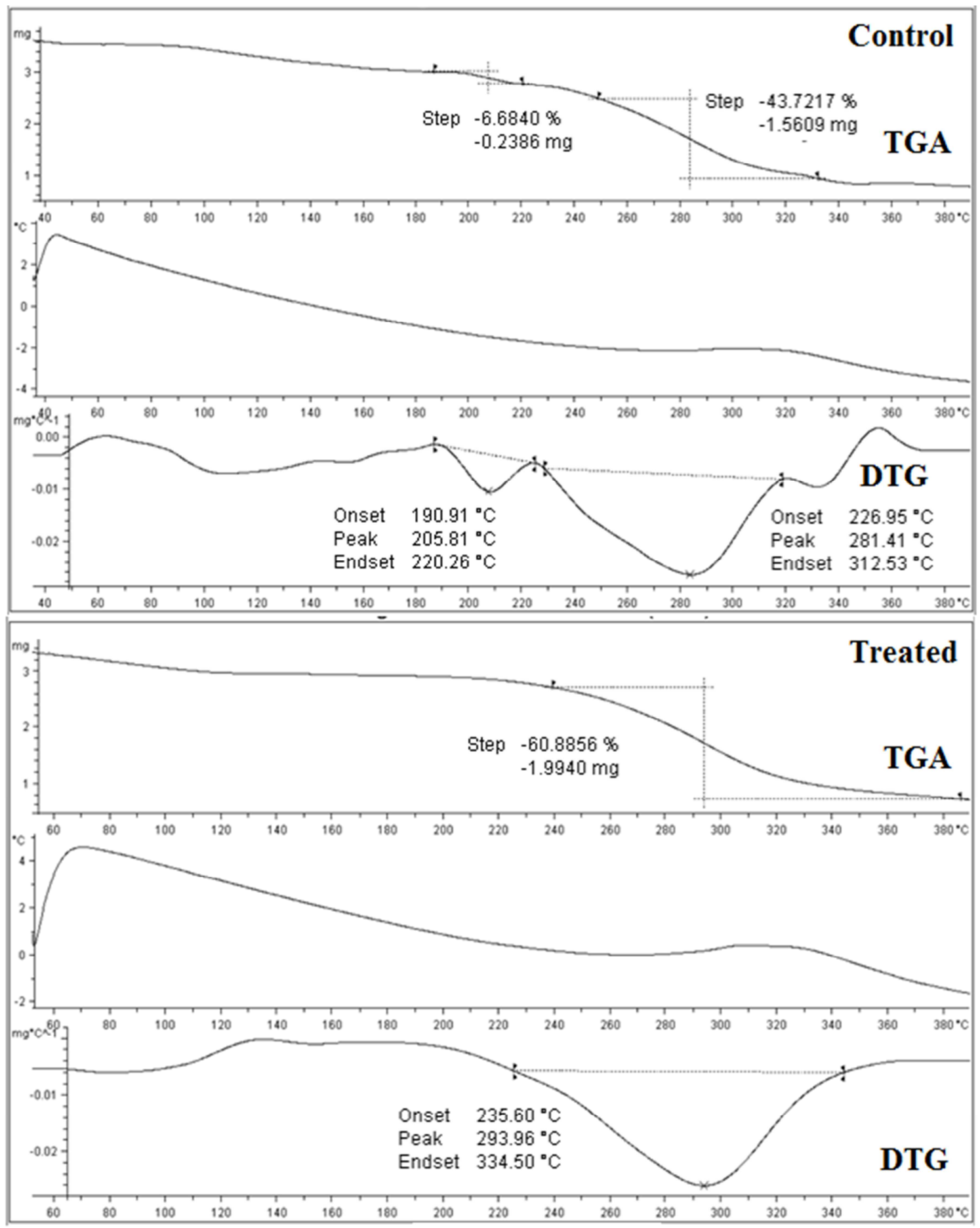

Temperature $\left({ }^{\circ} \mathrm{C}\right)$

Figure 5. TGA thermograms of the control and treated MMTO.

\subsection{FT-IR Spectroscopy}

FT-IR spectroscopy was used to investigate the vibrational functional groups present in the control and treated peptone samples. The FT-IR spectra of control and treated peptone samples are depicted in Fig. 6. The vibrational bands at 3066 and $3060 \mathrm{~cm}^{-1}$ were due to $\mathrm{O}-\mathrm{H}$ or $\mathrm{N}-\mathrm{H}$ stretching in the control and treated peptone samples. The FT-IR peaks in the region of 2817-2893 $\mathrm{cm}^{-1}$ and 2833-
$2879 \mathrm{~cm}^{-1}$ in the control as well as treated samples, were due to $\mathrm{C}-\mathrm{H}$ stretching vibrations. The characteristic vibrational peaks at 1589 and $1635 \mathrm{~cm}^{-1}$ in the control sample was mainly due to amide-II and amide-I bending peaks, respectively. However, in the treated peptone these peaks were noticed at 1546 and $1641 \mathrm{~cm}^{-1}$. The vibrational bands at 1400,1336 and $1245 \mathrm{~cm}^{-1}$ were due to $\mathrm{O}-\mathrm{H}$ or $\mathrm{C}$ $\mathrm{H}, \mathrm{N}=\mathrm{O}$ or $\mathrm{C}-\mathrm{N}$ bending peaks in the control sample. However, the treated sample showed these peaks at 1402 , 
1338 and $1245 \mathrm{~cm}^{-1}$. The C-O stretch was noticed at 1155 and $1124 \mathrm{~cm}^{-1}$ in the control and treated samples. The bands at $1245 \mathrm{~cm}^{-1}$ in the control and treated peptone might also attributed to $\mathrm{PO}^{2-}$ asymmetric phosphate stretching of phosphodiester groups. The FT-IR peaks at 1070 and 1082

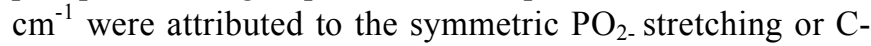
O-C stretching from the phospholipids. The FT-IR peaks at 921 and $979 \mathrm{~cm}^{-1}$ were due to C-O-C deformation bands. Overall, the results showed upward shifting in FT-IR peaks of the treated sample $2817 \rightarrow 2833 \mathrm{~cm}^{-1,} 1635 \rightarrow 1641 \mathrm{~cm}^{-1}$, and $1070 \rightarrow 1082 \mathrm{~cm}^{-1}$, as compared to the control. It was reported that frequency of any functional group is directly proportional to the force constant [28]. Thus, it assumed here that biofield energy treatment had perhaps caused an increase in force constant of bonds such as C-H, N-H I, and $\mathrm{PO}_{2-}$ groups in the treated sample.

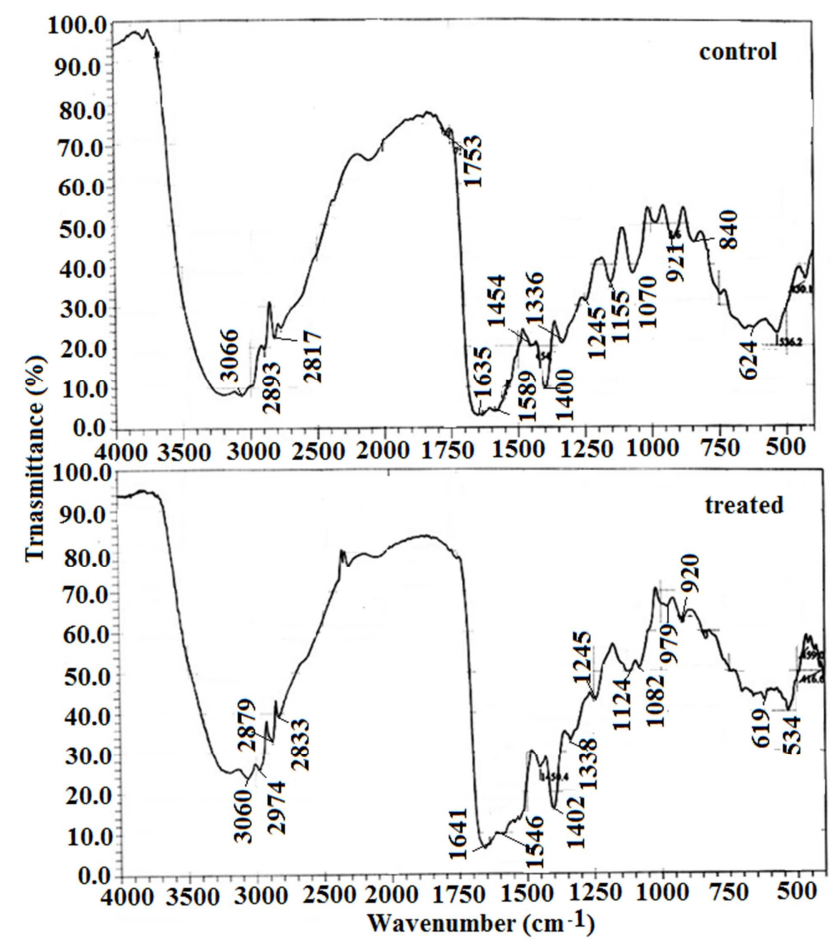

Figure 6. FT-IR spectra of the control and treated peptone.

The FT-IR spectra of the control and treated MMTO samples are presented in Fig. 7. The MMTO samples are mainly consist of casein hydrolysate, pineapple powder, activated charcoal and agar as constituents [9]. The FT-IR spectrum of the control and treated sample showed a broad peak at 3332 and $3317 \mathrm{~cm}^{-1}$ which were due to $\mathrm{O}-\mathrm{H}$ or $\mathrm{N}-\mathrm{H}$ stretching vibrations. The typical $\mathrm{C}-\mathrm{H}$ stretching vibration peaks in the control sample were observed in the region of 2817-2895 $\mathrm{cm}^{-1}$. The treated sample showed these peaks at $2833-2895 \mathrm{~cm}^{-1}$. The vibration bands at 1596 and $1606 \mathrm{~cm}^{-1}$ were due to amide II bending in the control and treated samples. These peaks were attributed to the presence of casein hydrolysate protein in the samples. The stretching band at $1732 \mathrm{~cm}^{-1}$ was mainly due to $\mathrm{C}=\mathrm{O}$ of the carboxylic group present in the control and treated samples. The absorption bands in the region of $1245-1342 \mathrm{~cm}^{-1}$ were due to
$\mathrm{C}-\mathrm{H}$ (bending), C-O (alcohol), C-N and O-H (carboxylic acid) in the control sample. However, the treated sample showed these peaks at 1244 and $1367 \mathrm{~cm}^{-1}$. The vibration bands at 1037 and $1035 \mathrm{~cm}^{-1}$ were due to $\mathrm{C}-\mathrm{O}$ or $\mathrm{C}-\mathrm{H}$ inplane stretching peaks [29]. Overall, the result showed the increase in the frequency of FT-IR peaks $2817 \rightarrow 2833 \mathrm{~cm}^{-1}$, and $1596 \rightarrow 1606 \mathrm{~cm}^{-1}$, in the treated sample as compared to the control. The increase in the frequency of these peaks might be attributed to the increase in force constant after biofield treatment.

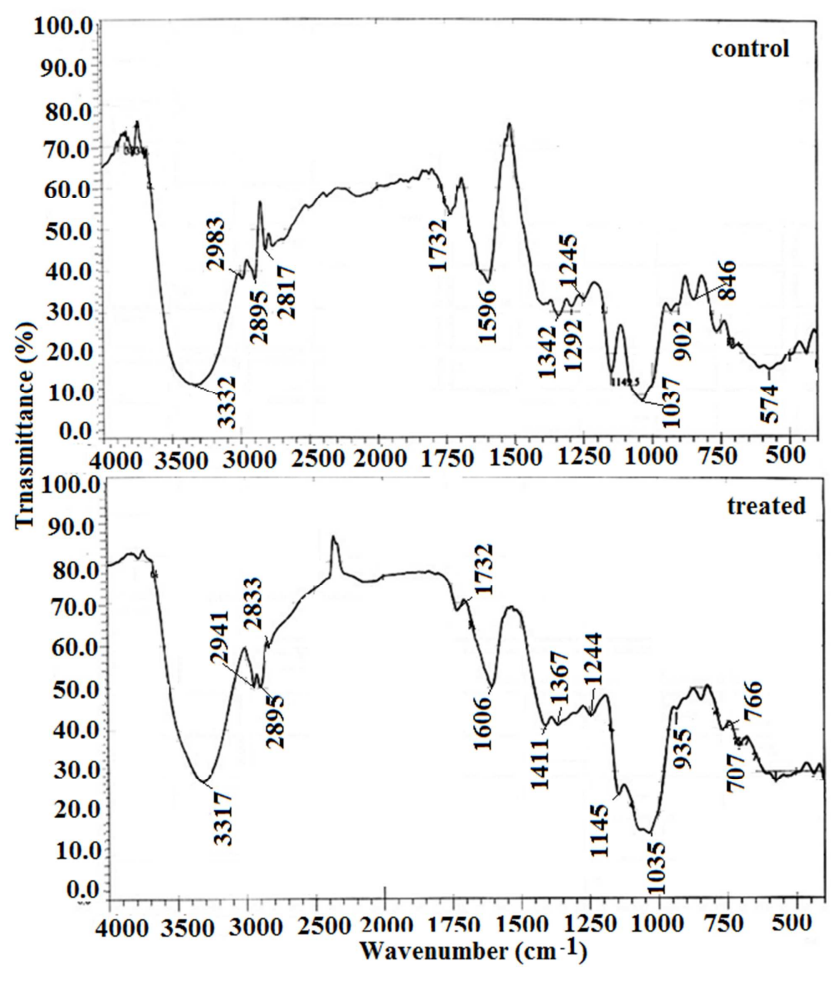

Figure 7. FT-IR spectra of the control and treated MMTO.

\subsection{Particle Size and Surface Area Analysis}

The particle size of the control and treated peptone were evaluated using laser particle size analyzer and data are presented in Fig. 8. The average particle size $\left(d_{50}\right)$ of the control peptone was $9.93 \mu \mathrm{m}$, and it was increased up to $10.85 \mu \mathrm{m}$ in the treated sample. Whereas, the size exhibited by $99 \%$ of particles $\left(d_{99}\right)$ of the control peptone was 96.96 $\mu \mathrm{m}$, and it was increased substantially to $137.13 \mu \mathrm{m}$ in the treated sample. The result suggested $9.3 \%$ and $41.4 \%$ increase in $\mathrm{d}_{50}$, and $\mathrm{d}_{99}$, respectively in the treated sample as compared to the control sample. It was previously reported that proteins have a stronger tendency of forming aggregate. They can form self-aggregates in a number of ways such as the formation of structural complexes, and multimeric native states with metal complexation [30-32]. These proteins have sufficiently strong inter-protein interactions which induce formation of bigger aggregates [33]. It is postulated that biofield energy may be interacted with protein assembly of treated peptone and caused bigger microparticle formation as compared to the control. 
The surface area of the control and treated peptone were evaluated by BET analyzer, and data are presented in Fig. 9. The surface area of the control peptone was $1.086 \mathrm{~m}^{2} / \mathrm{g}$ and it was increased slightly to $1.135 \mathrm{~m}^{2} / \mathrm{g}$ in the treated sample. The result suggested $4.3 \%$ increase in surface area of the treated sample as compared to the control. It was reported that particle size is inversely proportional to the surface area. The increase in particle size decreases the surface area and vice versa. However, the results are contrary, which perhaps may be due to the pore formation on the surface of the treated protein (peptone) that might increase in surface area of the treated sample [34].

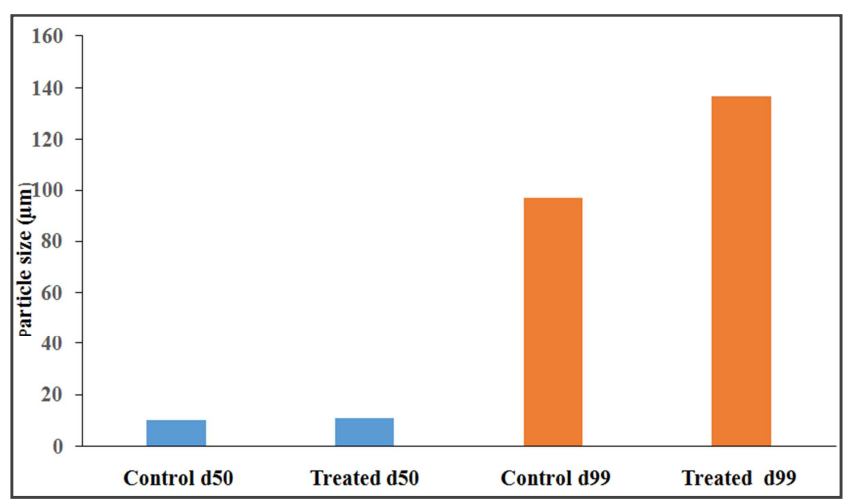

Figure 8. Particle size (d50 and d99) of the control and treated peptone.

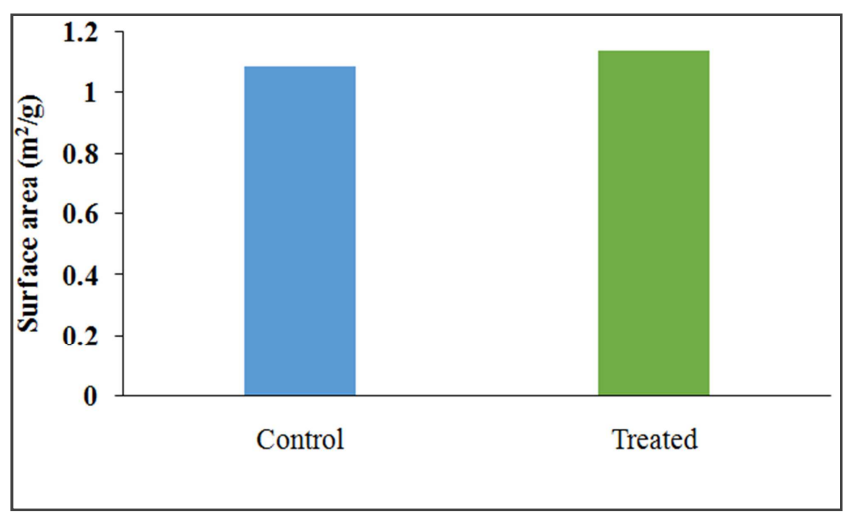

Figure 9. Surface area of the control and treated peptone.

\section{Conclusions}

In summary, the results demonstrated the impact of $\mathrm{Mr}$. Trivedi's biofield energy treatment on physical, thermal and spectral properties of the peptone and MMTO. The XRD results of control and treated peptone showed the presence of both amorphous and semi-crystalline regions. Additionally, the intensity of few XRD peaks were increased might be due to tensile stress in the treated sample as compared to the control. The DSC studies on treated peptone showed an increase in thermal denaturation temperature of the sample which may be correlated to increase in the thermal stability. Additionally, the exothermic peak due to protein aggregation was increased in treated peptone $\left(280^{\circ} \mathrm{C}\right)$ as compared to the control $\left(270^{\circ} \mathrm{C}\right)$. TGA analysis supported the DSC observation as the onset of thermal degradation was increased in treated sample $\left(172^{\circ} \mathrm{C}\right)$ with respect to the control $\left(170^{\circ} \mathrm{C}\right)$. TGA analysis of MMTO showed an increase in $T_{\max }$ of the treated sample that indicated the increase in the thermal stability after biofield treatment. The FT-IR spectroscopic analysis of the treated peptone showed an upward shift in frequency of C-H $\left(2817 \rightarrow 2833 \mathrm{~cm}^{-1}\right)$, and amide I $\left(1635 \rightarrow 1641 \mathrm{~cm}^{-1}\right)$ stretching as compared to the control. Similarly, the treated MMTO also showed increase in the frequency of $\mathrm{C}-\mathrm{H}$ and amide-I bond that may be related to increase in bond force constant of the treated sample. Particle size analysis of the treated peptone showed an increase in $d_{50}$ and $d_{99}$ by $9.3 \%$ and $41.4 \%$. Contrarily, the surface area of the treated peptone was also increased by $4.3 \%$. The increase in thermal denaturation temperature and thermal stability of peptone, MMTO might improve its uses as a growth medium for tissue culture applications.

\section{Abbreviations}

XRD: X-ray diffraction, DSC: Differential scanning calorimetry, TGA: Thermogravimetric analysis, Fourier transform infrared (FT-IR), CAM: Complementary and alternative medicine, MMTO: Malmgren modified terrestrial orchid.

\section{Acknowledgments}

The authors wish to thank all the laboratory staff of MGV Pharmacy College, Nashik for their kind assistance during handling the various instrument characterizations. The authors would also like to thank Trivedi Science, Trivedi Master Wellness and Trivedi Testimonials for their support during the work.

\section{References}

[1] Surachi U (1999) Basic techniques in animal cell culture. Drug Delivery System Workshop, Bangkok.

[2] Neema R, Khare S (2012) An animal cell culture: Advance technology for modern research. Adv Biosci Biotechnol 3: 219-226.

[3] Madigan M, Martinko J (2005) Brock Biology of Microorganisms (11thedn), Prentice Hall, NJ.

[4] https://en.wikipedia.org/wiki/Growth_medium (Accessed on 26 October 2015).

[5] http://himedialabs.com/TD/RM001.pdf (Accessed on 26 October 2015).

[6] Wijayanti HB, Bansal N, Deeth HC (2014) Stability of whey proteins during thermal processing: A Review. Compr Rev Food Sci F 13: 1235-1251.

[7] Marshall G, Valtchev P, Dehghani F, Gomes VG (2015) Thermal denaturation and protein stability analysis of Haliotis rubrahemocyanin. J Therm Anal Calorim 1-7 (In Press).

[8] Bischof JC, He X (2005) Thermal stability of proteins. Ann N Y Acad Sci 1066: 12-33. 
[9] http://himedialabs.com/TD/PT068.pdf (Accessed on 26 October 2015).

[10] Uchida S, Iha T, Yamaoka K, Nitta K, Sugano H (2012) Effect of biofield therapy in the human brain. J Altern and Complement Med 18: 875-879.

[11] Wilson CA (2011) Healing power beyond medicine. John Hunt Publishing Ltd, UK.

[12] Warber SL, Cornelio D, Straughn J, Kile G (2004) Biofield energy healing from the inside. J Altern Complement Med 10: 1107-1113.

[13] Prakash S, Chowdhury AR, Gupta A (2015) Monitoring the human health by measuring the biofield "aura": An overview. IJAER 10: 27637-27641.

[14] Barnes PM, Powell-Griner E, McFann K, Nahin RL (2004) Complementary and alternative medicine use among adults: United States, 2002. Adv Data 343: 1-19.

[15] Trivedi MK, Patil S, Shettigar H, Bairwa K, Jana S (2015) Phenotypic and biotypic characterization of Klebsiella oxytoca: An impact of biofield treatment. J Microb Biochem Technol 7: 203-206.

[16] Nayak G, Altekar N (2015) Effect of biofield treatment on plant growth and adaptation. J Environ Health Sci 1: 1-9.

[17] Trivedi MK, Patil S, Tallapragada RMR (2015) Effect of biofield treatment on the physical and thermal characteristics of aluminium powders. Ind Eng Manag 4: 151.

[18] Trivedi MK, Patil S, Shettigar H, Bairwa K, Jana S (2015) Effect of biofield treatment on spectral properties of paracetamol and piroxicam. Chem Sci J 6: 98.

[19] Trivedi MK, Nayak G, Patil S, Tallapragada RM, Jana S, et al. (2015) Bio-field treatment: An effective strategy to improve the quality of beef extract and meat infusion powder. J Nutr Food Sci 5: 389.

[20] Namazu T, Takemoto H, Inoue S (2010) Tensile and creep characteristics of sputtered gold tin eutectic solder film evaluated by XRD tensile testing. Sensor Mater 22: 13-24.

[21] Tang CH, Chen Z, Li L, Yang XQ (2006) Effects of transglutaminase treatment on the thermal properties of soy protein isolates. Food Res Int 39: 704-711.

[22] Bell LN, Touma DE (1996) Glass transition temperatures determined using a temperature cycling differential scanning calorimeter. J Food Sci 61: 807-810.
[23] Gioia LD, Cuq B, Guilbert S (1999) Thermal properties of corn gluten meal and its proteic components. Int J Biol Macromol 24: 341-350.

[24] Tang C, Yang XQ, Chen Z, Wu H, Peng ZY (2005) Physicochemical and structural characteristics of sodium caseinate biopolymers induced by microbial transglutaminase. J Food Biochem 29: 402-421.

[25] Arntfield SD, Murray ED (1981) The influence of processing parameters on food protein functionality I. Differential scanning calorimetry as an indicator of protein denaturation. Can I Food Sc Tech J 14: 289-294.

[26] Privalov PL (1982) Stability of proteins. Proteins which do not present a single cooperative system. Adv Protein Chem 35: $1-104$

[27] Szabo L, Cik G, Lensy J (1996) Thermal stability increase of doped poly (hexadecylthiophene) by $\gamma$-radiation. Synt Met 78 : 149-153.

[28] Pavia DL, Lampman GM, Kriz GS (2001) Introduction to spectroscopy. (3rdedn), Thomson Learning, Singapore.

[29] Agarry SE, Ogunleye OO (2015) Bioadsorption of 2, 6dichlorophenol from aqueous solution onto plantain and pineapple peels mixture used as adsorbent: Optimization studies based on taguchi method, batch equilibrium, and kinetic modelling. Chem Mater Res 7: 1-14.

[30] Midelfort KS, Wittrup KD (2006) Context-dependent mutations predominate in an engineered high-affinity single chain antibody fragment. Protein Sci 15: 324-334.

[31] Hooper NM (1994) Families of zinc metalloproteases. FEBS Lett 354: 1-6.

[32] Wiseman RL, Powers ET, Kelly JW (2005) Partitioning conformational intermediates between competing refolding and aggregation pathways: Insights into transthyretin amyloid disease. Biochemistry 44: 16612-16623.

[33] Amin S, Barnett GV, Pathak JA, Roberts CJ, Sarangapani PS (2014) Protein aggregation, particle formation, characterization \& rheology. Curr Opin Colloid Interface Sci 19: 438-449.

[34] Trivedi MK, Patil S, Mishra RK, Jana S (2015) Thermal and physical properties of biofield treated bile salt and proteose peptone. J Anal Bioanal Tech 6: 256. 